\title{
Melchor Cano and the Spirituality of St. Ignatius Loyola: The Censura y parecer contra el Insituto de los Padres Jesuitas
}

\author{
Terence O'Reilly \\ University College Cork, Ireland \\ Terence.OReilly@ucc.ie
}

\begin{abstract}
The leading critic in Spain of the early Society of Jesus and its founder was the Dominican theologian Melchor Cano, who believed that the spirituality of Ignatius and his companions was a form of illuminism. During the 1550 se set out his reasons for thinking this in his Censura y parecer contra el Insituto de los Padres Jesuitas, a document he intended to show to the pope. It survives in a number of manuscripts, one of them in the British Library in London. The present article traces the history of the text, which was long considered lost, and examines its portrayal of Ignatius, the Spiritual Exercises, and the Society. It concludes with a critical edition of the British Library manuscript.
\end{abstract}

\section{Keywords}

Ignatius of Loyola - illuminism - Melchor Cano - Spiritual Exercises - Inquisition Society of Jesus

* The present article is a revised and updated version of two essays that originally appeared separately. The first, "Melchor Cano and the Spirituality of St Ignatius Loyola," was published in Ignacio de Loyola y su tiempo, ed. Juan Plazaola (Bilbao: Mensajero, 1992), 369-80. It was reprinted as Essay IV in Terence O'Reilly, From Ignatius Loyola to John of the Cross (Aldershot: Variorum, 1995). The second, "Melchor Cano's Censura y parecer contra el Instituto de los Padres Jesuitas: A transcription of the British Library manuscript," was published as Essay v in O'Reilly, From Ignatius Loyola to John of the Cross.

(C) O'REILLY, 2017 | DOI 10.1163/22141332-00403001

This is an open access article distributed under the terms of the Creative Commons Attribution-

Noncommercial 4.0 Unported (CC-BY-NC 4.0) License. http://creativecommons.org/licenses/by-nc/4,0623 02:53:10PM 
One of the most ardent early critics of the spirituality of Ignatius Loyola (c.1491-1556) was the Dominican theologian Melchor Cano (c.1509-6o), who believed it was an offshoot of the kind of illuminism practised by the alumbrados or dexados, a group whose teachings were condemned in 1525 by the Inquisition of Toledo. ${ }^{1}$ Cano's views on the alumbrados may be studied in detail in his lengthy critique of the catechism of Bartolomé de Carranza (1503-76), ${ }^{2}$ but his reasons for associating Ignatius with the illuminists are not documented so fully. Between 1556 and 1558 he wrote a number of letters in which he affirmed that the Society was a heretical force whose Exercises were undermining church and state, but he declined to set out fully his reasons for his conviction, stating more than once that they were not "para carta." ${ }^{3}$ In one letter, dated October 5,1558 , he indicated that he had put his views in writing, and intended to show the document to Pope Paul IV (r.1555-59), but this treatise was subsequently lost: Alfonso de Vargas, writing in 1641, claimed to have seen it in manuscript in Cano's own hand, but Fermín Caballero (1800-76), in his biography of 1871 , reported that it could not be traced. ${ }^{4}$ In 1877 , however, Pascual de Gayangos (1809-97) drew attention to an unpublished manuscript in

1 On the life of Cano, and his hostility to the Society of Jesus, see C. Pozo, "Cano, Melchor," in Diccionario histórico de la Compañía de Jesús, ed. Charles E. O’Neil, S.J., and Joaquín Domínguez, S.J. (Madrid/Rome: Universidad Pontificia Comillas / Institutum Historicum Societatis Iesu, 2001), 1:636-37; Antonio Osuna Fernández-Largo, O.P., "Cano, Melchor," in Diccionario biográfico español, ed. Icíar Gómez Hidalgo (Madrid: Real Academia de la Historia, 2009-2013), 11:48-55. The edict of 1525 may be examined in the appendices to Antonio Márquez, Los alumbrados: Orígenes y filosofía, 1525-1559 (Madrid: Taurus, 1972; second edition 1980). Cano's objections to the Jesuits have been studied in detail by Guido Mongini, "Ad Christi similitudinem": Ignazio di Loyola e i primi gesuiti; Studi sulle origini della Compagnia di Gesù (Alessandria: Orso, 2011), passim, and Enrique García Hernán, Ignace de Loyola: Biographie: Édition revue et augmentée (Paris: Seuil, 2016), 436-48 (the first edition of this work was published in Madrid, 2013). On the crisis that formed the context of Cano's views see Doris Moreno, "Los jesuitas, la Inquisición y la frontera espiritual de 1559," Bulletin of Spanish Studies 92, no. 5 (2015): 655-75.

2 The Qualificación hecha por los Maestros Cano y Cuevas del catechismo [y de otros escritos] 1558-1559 has been published in Fray Bartolomé de Carranza: Documentos históricos, ed. J. Ignacio Tellechea Idígoras (Madrid: Real Academia de la Historia, 1981), 6:225-384. On Cano and Carranza see Rady Roldán Figueroa, "Ignatius of Loyola and Juan de Ávila on the Ascetic Life of the Laity," in A Companion to Ignatius of Loyola: Life, Writings, Spirituality, Influence, ed. Robert Aleksander Maryks (Leiden: Brill, 2014), 159-78, here 159-60.

3 See his letters to Miguel de Arcos and M. Venegas in Fermín Caballero, Conquenses ilustres, vol. 2: Melchor Cano (Madrid: Colegio Nacional de Sordomudos y de Ciegos, 1871), 499-500.

4 Caballero, Conquenses ilustres, 110, 351, 354. 
the British Library attributed to Cano and entitled, Censura y parecer que dio contra el Instituto de los PP. Jesuitas. ${ }^{5}$ This document, which internal evidence permits us to date between $155^{1}$ and $155^{6}$, appears to be the one Cano mentioned. ${ }^{6}$ The pages that follow trace the history of the text, consider the light it throws on Cano's view of Ignatius, the Spiritual Exercises, and the Society of Jesus, and present an edition of the British Library manuscript.

\section{History of the Text}

The earliest references to the Censura occur in letters written in Spain during the 155 os. In October 1557, Melchor Cano was elected provincial at a chapter of the Dominicans in Segovia, but for various reasons Rome did not ratify the election, and he returned to the house of San Esteban in Salamanca where he was prior. A few months later, in February 1558, he set out for Rome in order to attend the general chapter which was scheduled for May $29,{ }^{7}$ and as the news of his journey spread through Castile it filled members of the Jesuit order with dismay. Rumor had it that he intended to confer with Pope Paul IV, about the Society of Jesus, and it was notorious that both men were implacably hostile to the new order. On April 4, Pedro de Ribadeneyra (1526-1611) wrote to Superior General Diego Laínez (1512-65), and warned him that he had heard, "que el Maestro Cano es provincial de su orden en Castilla, y que va a Roma a su capítulo, con determinación de desengañar al papa en lo que toca a la

5 Pascual de Gayangos, Catalogue of the Manuscripts in the Spanish Language in the British Library (London: British Museum, 1875-93; reprinted 1976), 2:178. The manuscript was included subsequently in the bibliographies of José Simón Díaz: Bibliografía de la literatura hispánica (Madrid: Consejo Superior de Investigaciones Científicas, 1967), 7:396, and Domínicos de los siglos xvi y xvii: Escritos localizados (Madrid: Fundación Universitaria Española, 1977), 110. I am grateful to Simon Tugwell, O.P. for drawing my attention to the manuscript, Professor Michelle Brown for her help in obtaining a microfilm, Dr. Barry Taylor of the British Library who supplied a description of Egerton MS. 453 and carefully checked my transcription, the late Professor J.S. Cummins for advice on the history of the text, and the late Janet Hamilton who answered my queries about Latin passages in the Censura.

6 British Museum Eg. 453 (fols. $91-105^{\mathrm{v}}$, including title page). The manuscript, which is written in a clear hand, is divided into fifteen sections of unequal length. At one point [Section 4], the author refers to an encounter with Laínez and Salmerón at the Council of Trent. This must have taken place during the second session of the council $\left[155^{-}-5^{2}\right]$ that Cano attended (Caballero, Conquenses ilustres, 75). Since it is understood throughout the document that the general of the Society is Ignatius, it must have been composed before his death in July 1556 .

7 Caballero, Conquenses ilustres, 110-11. 
Compañía, etc., y que para esto es menester mucho favor." ${ }^{\text {A }}$ At about the same time the alarm felt in certain quarters was voiced by Giovanni Battista Ribera, who solemnly declared, "Imminet ruinae universae Societatis," and although the melodrama of the phrase amused Diego Laínez he was well aware of how grave the crisis was. ${ }^{9}$

Popular rumor about Cano's intentions was not mistaken. In the event he was obliged to pause in his journey at Rosas, because of diplomatic tensions between the papacy and Spain. A few months later, in October, he wrote from Valladolid to the royal confessor, Fray Bernardo de Fresneda (1495-1577), and explained that he was deeply disappointed, not only because in Rome he had hoped to regularize his election, but because he had planned to show the pope what he had written about the Society, and thereby forestall the harm he feared it would do:

Allende de lo que a mí tocaba yo pretendía comunicar con el papa los apuntamientos que tengo contra yerros desta nueva compañía, por descargar mi conciencia y tentar si por aquella vía se ponía algún reparo a tanto mal como yo temo desta gente. ${ }^{10}$

What did these notes or jottings (apuntamientos) contain? Ever since 1548, when Cano had begun to attack the Jesuits in public, the general in Rome had received from members of the Society in Spain a steady flow of information about his campaign, and in one of these bulletins there is evidence that as early as 1555 the contents of the Censura were familiar to Dominicans in Castile. On February 14 in that year, Antonio de Araoz (1515-73) reported from Valladolid that some friendly colleagues of Cano had explained why he looked on Ignatius with such suspicion:

Algunos padres dominicos doctos, que quisieron saver dél sus fundamentos, me los dixieron, y son tan sin fundamento, que es lástima ver en tal porfía vn hombre de sus partes y letras. Estos Padres quedan bien satisfechos, y lo dizen á vozes. Dizen que dize de V.P.: Primero, que, ablándole, luego V.P. le descubrió y dixo reuelaçiones, y avn creo que le confesó que avía ydo huyendo de España. 2, que V.P. le alabó mucho á vno

8 Pedro de Ribadeneyra, Confesiones, epistolae aliaque scripta inedita (Madrid: Ibérica, 1920-23), 1:292.

9 Mario Scaduto, L'epoca di Giacomo Laínez: Il Governo, 1556-1565 (Rome: La Civiltà Cattolica, 1964), 539-41.

10 Caballero, Conquenses ilustres, $53^{2-33}$. 
que comulgaba cada día, y que haziéndole venir delante dél, alló que era mentecapto, de que V.P. quedó bien corrido. 3, que asímismo V.P. le alabó mucho á çierto médico (creo era Inigo López), et tamen él supo que avía resignado ciertos beneficios, creo, curados á vn sobrino suyo, que estaba en Spaña. 4, que, yendo con V.P. á casa de vn cardenal, dixo V.P. á vn page, que dixiese al cardenal que estaba allí Ignatio, ó el confesor de madama, ó el prepósito de la Compañía; y también dize de vnos palos ó diferençias, y de çierto oficio que V.P. hizo en ello. Destas cosas infiere él vna conclusión arto de reyr y de llorar. También dize, creo que él, que la Compañía no fué aprobada canónicamente, y otras cosas indignas de dezirlas él, y de scribirlas yo. Gloria á Dios..11

The summary is secondhand and the tone derisory, but the points outlined clearly correspond to passages in the Censura as we know it now. ${ }^{12}$

The letter of Araoz was not the general's only source of information about the Censura. At some point (the precise date is not known) members of the Society managed to procure a copy of the text, perhaps from Dominicans critical of Cano, and they sent it secretly to Rome, where it was filed away. ${ }^{13}$ Ribadeneyra probably had it in mind when, years later, he alluded to the Censura in a manuscript entitled De las persecuciones de la Compañía, which was left unpublished on his death. In the chapter on la persecución de Melchor Cano he wrote:

Viviendo él (a lo que entiendo) se escribió un papel contra nuestro Instituto y contra la santidad de N.B.P. Ignacio y la de sus hijos, que entonces andaba, y después acá ha andado, en manos de algunos frailes de Santo Domingo.

He went on to wonder if the document had been written by Cano himself, or dictated to others who had added points of their own. He himself did not know:

No sé si este papel lo compuso el mismo M. Cano, o algún otro u otros frailes de su Orden, escribiendo lo que decía, y añadiendo por ventura cosas recogidas de hablillas y cuentecillos impertinentes de gente ociosa. ${ }^{14}$

\footnotetext{
11 Epistolae mixtae ex variis Europae locis ab anno 1537 ad 1556 scriptae (Madrid: Avrial, 1898-1900), 4:548.

12 The passages concerned may be seen in the Censura at fol. $94^{\mathrm{r}}-95^{\mathrm{v}}$ and $97^{\mathrm{r}}-97^{\mathrm{v}}$.

13 Antonio Astraín, Historia de la Compañía de Jesús en la asistencia de España (Madrid: Sucesores de Rivadeneyra, 1902-25), 1:324n2.

14 Cartas de San Ignacio de Loyola (Madrid: Aguado, 1887-89), 1:525.
} 
The death of Paul IV on August 18, 1559, and the election of his successor Pius IV (r.1559-1565) later that year, eased the situation of the Society as a whole, and in Spain the change of atmosphere was confirmed when Cano died suddenly in Toledo on September 30, $1560 .{ }^{15}$ Copies of the Censura, however, continued to circulate, and they proved to be of interest, naturally enough, to critics of the Jesuits who were eager to make a case against the order. One of these was the Catholic apologist Gaspar Schopp or Scioppius (1576-1649), the author of many anti-Jesuit tracts that were eventually placed on the Index. ${ }^{16}$ Under the pseudonym of Alfonso de Vargas of Toledo he published a work in the 1630 , in which he mentioned a treatise of Cano entitled Iudicio de secta jesuitarum. ${ }^{17}$ This, he affirmed, survived in a manuscript written by the author himself. He went on to quote a passage from it, virtually identical with one in the Censura as it has come down to us:

Si me acerco a tratar de los fundadores de esta Compañía, es su general un cierto Iñigo, que huyó de España, cuando la Inquisición quería prenderle, por haberse dicho que era herege de la secta de los Alumbrados. Fue a Roma, pidió ser juzgado por el Papa, y como no había quien le acusase, fue absuelto. ${ }^{18}$

At about the same time the Censura was quoted extensively in another antiJesuit work published in Spain under the title Juicio universal y parto singular de conceptos ocultos. Its anonymous author included among his sources "el insigne Tratado del Sr Obispo de Canarias." ${ }^{19}$ In this light but stinging jest the Society of Jesus is put on trial before a judge named Juicio Humano. The chief prosecutor is Cano, and the defendants are the five Jesuits singled out in the Censura: Iñigo, Salmerón, Laynez, Torres, and Fabio. The prosecutor's

15 Caballero, Conquenses ilustres, 135.

16 J. Mercier, "Schopp (Gaspard)," in Dictionnaire de théologie catholique, 14.2: cols. 1571-74; Enrique García Hernán, "Jesuitas contra dominicos: El caso del jesuita Pierre Poussines y el dominico Melchor Cano," in La memoria escrita de los dominicos, ed. Rosa María Alabrús (Barcelona: Arpegio, 2012), 43-57, here 48.

17 Alfonso de Vargas, Relatio ad reges et principes christianos de stratagematis et sophismatis politicis Societatis Jesu ad monarchiam orbis terrarum sibi conficiendam (1631). The title page gave the place of printing as Rome. García Hernán, "Jesuitas contra dominicos," 48n15, notes six further editions printed between 1632 and 1665 .

18 Quoted in Caballero, Conquenses ilustres, 352, 401.

19 The anonymous author was a canon of Salamanca, Juan Balboa de Mongrovejo, and the work was printed in 1627: see García Hernán, “Jesuitas contra dominicos," 47-48. 
case includes several passages, printed in italics, which are drawn from the Censura. They concern the mission of Pierre Favre (1506-46) to Germany (cf. Censura, fol. $95^{\mathrm{v}}$ ), the behavior of Diego Laínez and Alfonso Salmerón $(1515-85)$ at Trent (cf. fol. $96^{r}$ ), the legality of the Society's approbation (cf. fols. $97^{\mathrm{r}}-97^{\mathrm{v}}$ ), its association with the sisters founded by the Countess of Guastalda (ibid.), and the sexual licence of some Jesuits $\left(\mathrm{cf}\right.$. fol. $\left.100^{\mathrm{v}}\right) \cdot{ }^{20}$ This pamphlet, which was banned by the Inquisition, does not appear to have survived into modern times, but manuscript versions are preserved in libraries in Coimbra and Vienna. ${ }^{21} \mathrm{~A}$ few decades later, in 1659 , the Censura was reproduced by a French Jesuit, Pierre Poussines (1609-86), in a history of the controversies between Dominicans and Jesuits. Although Superior General Goswin Nickel (1584-1664), refused permission for the book to be published, he allowed it to be read within the Society itself. ${ }^{22}$

In the century following, anti-Jesuit feeling came to a head in the events that led Pope Clement XIV (r.1769-1774) to suppress the Society of Jesus in July 1773. A flood of literature hostile to the order appeared in print, and it seems to have included the Censura. On June 20, 1777, the inquisitor general and bishop of Salamanca, Felipe Beltrán (1704-83), prohibited a list of writings, among them, "un papel impreso en quarto en quatro hojas útiles, con este título: Censura y parecer que dio el P.M. Fr. Melchor Cano, de la Orden de Predicadores, contra el instituto de los Padres Jesuitas: sin fecha, ni lugar de impresión." ${ }^{33}$ Early in the last century Miguel Mir (1841-1912) claimed to have seen a copy of this edition, but he did not indicate where he had come across it. ${ }^{24}$

The study of the Censura in modern times may be said to have begun with the publication in 1871 of Fermín Caballero's biography of its author. He was aware that the text of Cano's work had circulated in manuscript in the seventeenth century and that it had been published in the eighteenth, but despite an extensive search he was unable to trace it. He concluded that it had been lost irretrievably, but he was not surprised, for it had become an embarrassment not only to Jesuits but to defenders of Cano's reputation:

Al cuidado que pondrían los hijos de San Ignacio en que pereciese escrito tan ofensivo, debieron unirse los deseos de los mismos devotos del

$20 \quad$ Caballero, Conquenses ilustres, 355-59.

21 Díaz, Bibliografía de la literatura hispánica, 12:570; Caballero, Conquenses ilustres, 356n1.

22 García Hernán, "Jesuitas contra dominicos," 50-51.

23 Caballero, Conquenses ilustres, 359.

24 Miguel Mir, Historia interna documentada de la Compañía de Jesús (Madrid: Ratés Martín, 1913), 2:620. 
Obispo renunciante, interesados en que desapareciese un lunar que, a su juicio, empañaba la buena memoria del famoso escritor. ${ }^{25}$

In 1900, Caballero's pessimistic conclusion was challenged by Miguel Mir. Writing anonymously in a collaborative work entitled Crisis de la Compañía de Jesús, he announced that he had seen a transcription of the Censura in the hand of Ramón Cabrera (1754-1833), a member of the Royal Spanish Academy. Although he did not know the source on which the transcription was based, he surmised that it had come from the library of the Dukes of Alba, a conjecture made plausible by the fact that Cano was closely associated with the Albas and had managed to convince them that his view of the Jesuits was correct. ${ }^{26}$ Mir went on to publish Cabrera's transcription in full, with some minor amendments of his own. ${ }^{27}$ Six years later, on December 11, 1906, the Crisis was placed on the Index. ${ }^{28}$ Meanwhile, in 1902, the Jesuit historian Antonio Astraín (1857-1928) had drawn attention to the manuscript version of the Censura in the archives of the Society of Jesus in Rome. He did not publish the text, but he provided a summary of its argument that included some quotations. These indicated that the manuscript in Rome differed in many small but significant details from the one transcribed by Cabrera, an important point in view of Ribadeneyra's reflections on its origins. Astraín, however, did not refer to the Cabrera manuscript, and he was apparently unaware of its publication by Miguel Mir. ${ }^{29}$ In 1913, a further version of the Censura appeared in Mir's posthumous work, Historia interna documentada de la Compañía de Jesús. It was based on two sources: the manuscript transcribed by Cabrera, and the rare copy of the eighteenth-century pamphlet that Mir said he had consulted. He did not refer to the earlier version in the Crisis, nor did he mention the manuscript in Rome,

25 Caballero, Conquenses ilustres, 360.

26 On Cano and the house of Alba see John W. O'Malley, S.J., The First Jesuits (Cambridge, MA: Harvard University Press, 1993), 293-94; Scaduto, L'epoca di Giacomo Laínez, 564.

27 Crisis de la Compañía de Jesús (Barcelona: Antoniana, 1900), 150-59. The book was published under the name of Segismundo Pey-Ordeix who indicated in the preface that he was not the author (9). Mir's reasons for choosing anonymity stemmed from his uneasy relations with the Society which he had left in 1891. On the background see Manuel Revuelta González, La Compañía de Jesús en la España contemporánea (Madrid: Universidad Pontificia Comillas, 1984-91), 2:694-701; Memorias del P. Luis Martín, ed. José Ramón Eguillor, Manuel Revuelta and Rafael María Sanz de Diego (Rome: Institutum Historicum Societatis Iesu, 1988), 2:553n81; Miquel Batllori, "Mir y Noguera (Michel)," in Dictionnaire de spiritualité, 10.2: cols. 1273-74.

28 Revuelta González, La Compañía de Jesús en la España contemporánea, 2:699n115.

29 Astraín, San Ignacio de Loyola, 1:321-40, 368-70. 
though he was evidently familiar with the work of Astraín. Ten years later, on May 2, 1923, the Historia interna was put on the Index. ${ }^{30}$

It might have been thought that the burst of interest in the Censura that occurred between 1900 and 1913 would inspire further research into the text and its history, but this is not, in fact, what happened. The publication of the Censu$r a$ by Miguel Mir was mentioned in a number of encyclopaedia articles about Cano, beginning with one by the Dominican P. Mandonnet (1858-1936), who in 1905 referred wittily to "la célèbre censure de Cano [...] dont tant d'auteurs ont parlé, et que presque personne n'a vue."31 References to Mir's edition were made also in articles by John R. Volz in 1908 and E. Lamalle S.J. (1900-89) in 1949. ${ }^{32}$ In more specialist studies, however, the Censura was often conspicuous by its absence. The Dominican Vicente Beltrán de la Heredia (1885-1973) considered Cano's attacks on the Jesuits in one of the chapters of Las corrientes de espiritualidad entre los dominicos de Castilla durante la primera mitad del siglo XVI (Salamanca, 1941), but at no point in his analysis did he mention Cano's text. Nor did he do so twelve years later in an article on Cano in the Dictionnaire de spiritualité. ${ }^{33}$ Jesuit specialists were often reticent too. In 1945, Feliciano Cereceda devoted forty-eight pages to a detailed account of Cano's relations with the early Society, but he did not refer to the Censura at any point, even though it is apparent from his footnotes that he knew the Historia interna of Mir. ${ }^{34}$ A year later, Ignacio Iparraguirre (1926-73), in the first part of his history of the Spiritual Exercises, referred in a footnote to the Roman manuscript and to Astraín's analysis of it, but he refrained from discussing the Censura in detail, and he made no mention of the editions of Mir. ${ }^{35}$ Constancio Gutiérrez, in his monograph of 1951 on Spaniards at the Council of Trent, also alluded to the manuscript of the Censura conserved in Rome, but he did not refer to the study of it by Astraín, nor did he mention Mir's editions of the text. ${ }^{36}$ In view

30 Mir, Historia interna, 2:621-31; Revuelta González, La Compañía de Jesús en la España contemporánea, 2:701nı20.

31 P. Mandonnet, O.P., "Cano, Melchior," Dictionnaire de théologie catholique, 2: cols. 1537-40.

32 John R. Volz, "Cano, Melchior," in The Catholic Encyclopaedia, 3:251-52; Edmond Lamalle, S.J., "Cano, Melchor," Enciclopedia cattolica, 3:533-34.

33 Vicente Beltrán de la Heredia, O.P., "Cano (Melchior)," in Dictionnaire de spiritualité, 7: cols. $73^{-} 76$.

34 Feliciano Cereceda, S.J., Diego Laínez en la Europa religiosa de su tiempo 1512-1565 (Madrid: Cultura Hispánica, 1945-46), 1:369-417. There is a reference to Mir at 372n5.

35 Ignacio Iparraguirre, S.J., Práctica de los Ejercicios de San Ignacio de Loyola en vida de su autor (1522-1556) (Rome: Institutum Historicum Societatis Iesu, 1946), 96.

36 Constancio Gutiérrez, S.J., Españoles en Trento (Valladolid: Consejo Superior de Investigaciones Científicas, 1951), 838-39. 
of this response by specialists it is not surprising, perhaps, that the Censura did not figure during the last century in the standard bibliographies of Gilmont and Daman, Iparraguirre, and Polgár ${ }^{37}$ nor that it received no mention in the studies of Ignatius and the early Society by Hugo Rahner (1900-68), Joseph de Guibert (1877-1942), and Ricardo García Villoslada (1900-91). ${ }^{38}$ The situation changed only in 1992, when an article about the British Library manuscript appeared, followed four years later by an edition of the text. ${ }^{39}$ The reasons for this lacuna are not clear. It may be significant, however, that in the early part of the last century most scholars interested in Cano belonged to religious orders. Their fidelity to the church may have made them reluctant to draw attention to the writings of Miguel Mir that the church had condemned. The matter requires further investigation.

\section{Cano and Ignatius}

At the beginning of the Censura Cano states the principle that if the Society is the work of God its founders must be holy men, for God builds on rock [fol. $\left.92^{\mathrm{v}}-93^{\mathrm{r}}\right]$. He goes on to give reasons for supposing that the reputed holiness of Ignatius is more apparent than real. First, he affirms that when Ignatius left Spain he was on the run from the Inquisition, who suspected him of being an alumbrado: "el General dellos es un Iñigo, el qual se escapó huyendo de España porque le quería coger la Inquisición, porque se decía ser de los Alumbrados, o Dexados." He implies in addition that when the Roman authorities later cleared Ignatius of heresy they were ignorant of the evidence against him: "Fuese a Roma, y pidió ser juzgado del Papa, y no habiendo quien le acusase fue dado por libre" [fol. $94^{\mathrm{r}}$ ].

The second reason Cano gives for being suspicious of Ignatius is more personal: he has met him several times, and on each occasion has found him

37 Jean François Gilmont and Paul Daman, Bibliographie ignatienne (1894-1957) (Paris: Desclée de Brouwer, 1958); Ignacio Iparraguirre, Orientaciones bibliográficas sobre San Ignacio de Loyola, second edition (Rome: Institutum Historicum Societatis Iesu, 1965); László Polgár, Bibliographie sur l'histoire de la Compagnie de Jésus 1901-1980 (Rome: Institutum Historicum Societatis Iesu, 1981-91).

38 Hugo Rahner, The Spirituality of St. Ignatius Loyola: An Account of Its Historical Development (Chicago: Loyola Press, 1980) (the German original was first published in 1947); Joseph de Guibert, La spiritualité de la Compagnie de Jésus: Esquisse historique (Rome: Institutum Historicum Societatis Iesu, 1953); Ricardo García Villoslada, San Ignacio de Loyola: Nueva biografía (Madrid: Editorial Católica, 1986).

39 See note 1 above. 
wanting in integrity. Their first encounter occurred when Cano, happening to be in Rome, decided to pay him a visit. He was taken aback when Ignatius, for no apparent reason, began to explain how he had been persecuted in Spain: "Estando el autor una vez en Roma deseó ver a Iñigo, y hablando con él, sin ningún propósito comenzó a hablar con él de su justicia, y de la persecución que le habían hecho en España y quán sin razón." Ignatius also recounted certain revelations he had received from God: "Y contó muchas y muy grandes cosas de las revelaciones que tenía de Dios, y eso sin haber ninguna necesidad" [fol. $94^{\mathrm{r}-\mathrm{v}}$ ]. From these remarks Cano drew the conclusion that Ignatius was vain and his revelations unworthy of credit, and he conceived a desire to know more about him and his companions. This first meeting is not dated, but if it was the origin of Cano's concern about the Society, as he implies, it probably occurred in 1542, the year when (according to one of his letters) he first began to think about the matter anxiously. ${ }^{40}$

Their second encounter (as Cano recounts it) took place over a meal. While they were at table, Ignatius praised a member of the Society who had a reputation for holiness, but when this person was summoned he made a number of statements that seemed to Cano unorthodox, though he could also tell he was either simple or unwell:

Yendo otra vez a comer con él, alabó a un Santo de su Compañía, el qual siendo llamado le pareció al Autor ser loco. Y siendo preguntado de cosas de Dios dixo muchas heregías; y aquello díxolo y hacíalo de idiota, que no sabía más.

Ignatius, who according to Cano found this incident embarrassing, explained to his visitor that the person in question was not a heretic, but someone with orthodox views who was not completely sound of mind: "Y yéndose de allí el sobredicho Santo, quedándose afrentado el Iñigo, dixo al Autor: 'Ese no es herege, es loco, y creo tiene lucida intervala; como aora es conjunción de luna, no está tan católico"' [ fol. 94v] ]. The reader sympathetic to Ignatius might surmise that he wished to make the point that when judging the orthodoxy of others one should proceed with discretion and kindness, a principle enunciated in the Exercises themselves (in the Presupposition that precedes the main

$40 \quad$ In his letter to Miguel de Arcos, written in 1556, Cano noted, "Sé que ha catorce años que pienso sobre ello" (Caballero, Conquenses ilustres, 499). But see García Hernán, Ignace de Loyola, 439, who considers the date of this encounter uncertain ("une incertitude plane sur la date exacte"); he argues that it may have occurred in 1539, and that Cano and Ignatius may have met earlier as well, in Salamanca in 1528 (223). 
text [Ex. 21]). ${ }^{41}$ This incident, however, merely deepened Cano's suspicion and distrust.

The occasion of their third meeting was a joint visit to see and talk with Cardinal Alessandro Farnese (1520-89). A page who came to greet them asked whose name he should give his master, and Ignatius promptly reeled off a list of his titles:

Ofrecióse otra vez que yendo a hablar al Cardenal Farnesio con él, salió un page, y preguntando, “¿Quién diré que es?” dixo bien alto: “Decid que es el Maestro Iñigo, o el General de los de la Compañía, o el confesor de Madama, que por qualquier nombre de estos os entenderá." ${ }^{42}$

This behavior showed Cano how conceited Ignatius was: "De lo qual infirió el Autor había allí mucho viento" [fol. $94^{\mathrm{v}}-95^{\mathrm{r}}$ ] Here the word "viento" recalls his earlier statement that God does not build on wind or sand [fol. $\left.92^{\mathrm{v}}\right]$.

Cano concludes his assessment of Ignatius with a story he was told by a Spanish cleric in Rome who enjoyed a reputation for holiness in spite of the fact (known to Cano) that he possessed two neglected benefices in Spain. When another cleric in the city had an argument with a layman and struck him, Ignatius intervened to make peace. The layman, who was prevented by canon law from hitting back, refused to forgive the insult to his honor, but Ignatius arranged a settlement, accepted by both sides, in which the cleric agreed to receive a beating before being reconciled with his foe. ${ }^{43}$ Cano, shocked, expressed the view that this solution was reprehensible, but he was assured that all had been arranged with the official permission of the vicar of Rome. From this incident, and his own meetings with Ignatius, Cano concluded that he was ignorant of divine and human law, and imprudent and indiscreet as well as vain: "De todas estas cosas coligió el Autor ignorancia así del derecho divino como del humano $[\ldots]$, igrande imprudencia y indiscreción, y gran vanidad de su trato!" [fol. $95^{\mathrm{v}}$ ].

41 See Michael Ivens, S.J., Understanding the Spiritual Exercises: Text and Commentary (Leominster: Gracewing, 1998), 23-25.

42 On Cardinal Alessandro Farnese and Madama, or Margaret of Austria (1522-86), see John W. O'Malley, S.J., The First Jesuits, 36, 71, 171, 191, 357, and his more recent study, The Jesuits and the Popes: A Historical Sketch of Their Relationship (Philadelphia: St. Joseph's University Press, 2016), 28-29.

43 The dispute in question took place between August 24 and September 2, 1545, and involved two Spanish gentlemen, Bustamante de Herrera and Puerto Carrero, who was in minor orders. This was noted by Miguel Mir, Historia interna, 2:623n4. See also García Villoslada, San Ignacio de Loyola, 540-41; García Hernán, Ignace de Loyola, 397. 


\section{The Spiritual Exercises}

Apart from a vivid portrait of Ignatius, the Censura sets out clearly Cano's reasons for being suspicious of the Spiritual Exercises, in which he found several features that reminded him of the alumbrados. ${ }^{44}$ First, he deplored the fact that they offered everyone the same spirituality of a contemplative kind, irrespective of different temperaments and callings. Augustine, he writes, distinguished different types of sanctity corresponding to the various humors, but the Society is not so discriminating: "estos tienen para todos unos mismos exercicios de contemplación, como no todos sean aptos para ella" [fol. 103 $]$. Here the term "contemplación" appears to be used not in the strictly Ignatian sense but with its traditional monastic connotations of infused prayer. In his critique of Carranza's catechism, Cano levelled a similar charge against his fellow Dominican Luis de Granada (1505-88), accusing him of having composed the Libro de oración y meditación in order to offer a contemplative spirituality to people living in the world, even though it would profit few of them. He believed it was not feasible to combine the active and contemplative lives, and he was concerned that people who tried to do so might neglect the works proper to their vocation. This had been the error of the alumbrados, who greatly prized prayer and contemplation, and who were led in their enthusiasm to abandon their responsibilities to home, work, and family: Cano feared that through the Exercises the same upheavals would occur. In his view, the Jesuits were closely related to the dexados, and valued contemplation and devotion just as highly. Satan could be expected to use these good things to lead souls astray once again, this time on a larger scale:

se transfigura algunas veces en ángel de luz, y alumbra y da sentimientos espirituales, y aun ayuda de esta suerte a muchos en el camino del cielo para después dar con otros muchos en el camino y hoyo del infierno, como tenemos exemplo manifiesto en España de los Alumbrados y Dexados que fueron primos hermanos de estos, los quales por devoción y

44 Cano's reservations about the Exercises, and those of his fellow Dominican Tomás de Pedroche, are examined in Terence O'Reilly, "The Spiritual Exercises and Illuminism in Spain: Dominican Critics of the Early Society of Jesus," in "Ite inflammate omnia": Selected Historical Papers from Conferences Held at Loyola and Rome in 2006, ed. Thomas M. McCoog, S.J. (Rome: Institutum Historicum Societatis Iesu, 2010), 199-228; Santiago Madrigal, S.J., "Melchor Cano y los primeros jesuitas," in Soli Deo gloria, ed. Elisa Estévez and Fernando Millán (Madrid: Universidad Pontificia Comillas, 2006), 279-96; Pierre Emonet, S.J., Ignatius of Loyola: Legend and Reality, trans. Jerry Ryan, ed. Thomas M. McCoog, S.J. (Philadelphia: St. Joseph's University Press, 2016), 31-33. 
contemplación y otras cosas divinas hicieron tanto y más fruto que estos Padres, aunque el provecho de esos es más universal [fol. $93^{\mathrm{r}-\mathrm{v}}$ ].

In a letter written on September 21, 1557, he was more specific. His correspondent, Juan de Regla, had informed him that the Marqués de Tavara was keen that the king should make the Ignatian retreat, and Cano in his reply set out his reasons for thinking that this would be disastrous. Since grace perfects nature, the spiritual exercises of a Christian should improve him in the performance of his duties. If, after his exercises, a cobbler or a cook plied his trade less effectively, he would not be tolerated, "por más que nos alegase que se da a devoción y meditación." This, however, is the effect of the Ignatian Exercises: they turn soldiers into women, and caballeros into hens, not lions. Tavara himself had taken them, and instead of becoming a better Christian he had become a poorer knight ("en ley de caballero desmedrado"). In this way, the Exercises were threatening to undermine the religious orders, the Spanish kingdom, and Christendom. ${ }^{45}$

Cano's second reservation about the Exercises was prompted by the importance he considered they accorded to affective spiritual experience. The person taking them, he writes, is given to understand that during the retreat he will experience the work of grace in his soul and be granted consolations. To make such a promise, he considers, is presumption, an attempt to force the hand of God. He affirms also that people taking the Exercises are encouraged to express in words the sensible graces they have received. This means, in practice, that during their meditations they are not only being nourished themselves but preparing nourishment for the person accompanying them (i.e. the director), an activity that must leave their souls unsatisfied:

ofreciéndose la buena consideración luego se ofrece el cómo se ha de decir; lo qual hace que ya el mantenimiento no harta del todo al alma pues no es comida para ella sola, sino para sí y su compañero con quien trata.

Such readiness to speak of one's spiritual experience is a sign, not of grace, but of the devil [fol. $105^{\mathrm{r}-\mathrm{v}}$ ]. In his comments on the catechism of Carranza Cano made a similar criticism of the alumbrados: they too set great store by affective experiences of God's love, seeking in them the kind of assurance of personal salvation that the Lutherans sought in faith. He therefore objected 
to Carranza's appeals to experience, including his use of sentir (a verb used abundantly in the Exercises). ${ }^{46}$

Cano's third objection to the Exercises concerned their encouragement of indifference as a means of discerning God's will. In general, he felt, the Society erred by according an excessive and distorted importance to conformity with the will of God:

estos levantan tanto el conformarse con la voluntad de Dios etiam in volito materiali que quieren decir que en ninguna causa nos entristezcamos, $o$ a lo menos parece que se debe temer no vengan a esto.

This kind and degree of detachment, he affirms, runs counter to the example of Christ. It is an indication of false piety, and one of the signs of the Last Times [fol. $104^{\mathrm{v}}$ ]. The same error, according to Cano, characterized the alumbrados. They carried such conformity to absurd lengths, believing that in doing so they were giving God glory. In their case, too, this teaching gave rise to an apparent imperturbability that St. Paul had identified as a sign of the Last Days. ${ }^{47}$

Cano's reservations about indifference underlay his views on the making of an election, which forms such an important part of the Exercises. He deplored the stipulation in Annotations Fourteen and Fifteen [Ex. 14, 15] that the giver of the Exercises should refrain from actively encouraging the retreatant to take religious vows, ${ }^{48}$ and in the Censura he refers critically to the advice that God should be allowed to work directly in the soul, disposing it in the choice it wishes to make:

tienen una cláusula no muy sana que dice que quamvis licitum sit apto ad cor complecti, consultius erit quod anima eius maneat in aequilibrio, para hacer lo que Dios le inspirare [fol. $\left.104^{\mathrm{r}}\right]{ }^{49}$

The reasons for his criticism on this point may be inferred from his comments on two passages in the catechism of Carranza. The first stated that one should

46 See the entry under sentir in Concordancia ignaciana: An Ignatian Concordance, ed. Ignacio Echarte, S.J. (Bilbao: Mensajero, 1996).

47 Fray Bartolomé de Carranza: Documentos históricos, ed. Tellechea Idígoras, 6:272.

48 O'Reilly, "The Spiritual Exercises and Illuminism in Spain," 209-10.

49 See Astraín, San Ignacio de Loyola, $369 n 1$, who surmises that Cano here had in mind two passages in the Spiritual Exercises: the fifteenth annotation [15] and the second point in the first time of making an election [179]. 
seek divine guidance in all decisions, even mundane ones. The second affirmed that people should not take solemn vows of chastity before reaching maturity, when they could evaluate their spiritual and corporal resources and, having done so, "escoger el estado que Dios les inspirase."50 These two counsels are close in spirit to the Ignatian election, as practised by the saint himself and recommended in the Exercises. In both of them, Cano discerned the imprint of the alumbrados, who sought direct guidance from the Lord in all areas of their lives: "los quales en todas las cosas humanas e divinas consultando por sí mesmos a Dios por el don de consejo que todos los justos tienen, pensavan seer alumbrados del Espíritu Sancto en todas sus consultas." ${ }^{\text {51 }}$ Cano objected to this way of discerning God's will because it undermined respect for reason, learning, and authority. ${ }^{52}$

At one point in the Censura Cano gives an example of an election that he considered reprehensible. When Dr. Pedro Ortiz (c.1501-48) was offered the chair of scripture in Alcalá, he requested a lengthy period of time in which to discern God's will..$^{53}$ Eventually, he accepted it on three conditions that in Cano's view were outrageous because they ran counter to the instituted procedures of the university. Cano later discussed the matter with the Jesuit Miguel de Torres (1509-93), who explained to him that Ortiz had behaved as he did because he felt unable in any other way to discern God's purposes: "dixo que como el Espíritu Santo no le inspiraba lo que había de hacer, que acordó pedir aquellas condiciones, pareciéndole que si se las concedían el Espíritu Santo quería fuese Catedrático." Torres, according to Cano, admitted that this procedure was "imperfect." For Cano it was totally misguided, a clear sign of the influence of illuminism: "He aquí muchos ramalazos de Alumbrados o Dexados" [fol. $\left.96^{\mathrm{v}}\right] \cdot .^{54}$

5o Fray Bartolomé de Carranza: Documentos históricos, ed. Tellechea Idígoras, 6:267.

51 Ibid., 6:268.

$5^{2}$ Ibid., 6:294, 268-69.

53 Pedro Ortiz and his connections with Ignatius and the Society are examined by Robert Aleksander Maryks, "Ignatius of Loyola and the Converso Question," in Maryks, A Companion to Ignatius of Loyola, 89-9o; Marcel Bataillon, Les jésuites dans l'Espagne du XVIe siècle, ed. Pierre-Antoine Fabre (Paris: Les Belles Lettres, 2009), 194-202; García Hernán, Ignace de Loyola, 434-37.

54 On Miguel de Torres see Bataillon, Les jésuites dans l'Espagne du XVIe siècle, 148-49, 203-22; García Hernán, Ignace de Loyola, 20n3, 437-38; Stefania Pastore, "Unwise Paths: Ignatius Loyola and the Years of Alcalá de Henares," in Maryks, Companion to Ignatius of Loyola, 27, 33, 40-42. 


\section{The Society of Jesus}

In the Censura Cano criticizes not only the Spiritual Exercises but several other aspects of the life of the Society of Jesus. A number of his comments call into question the nature and extent of the approval it had received from Pope Paul III (r.1534-49). This approval was granted, he observes, before the constitutions of the Society had been drawn up, a break with precedent: neither the Franciscans nor the Dominicans were approved until the pope had examined their rules. In addition, the Jesuits had failed to observe a strict limitation of their numbers on which the pope had insisted $\left[97^{\mathrm{r}-\mathrm{v}}\right] .{ }^{55} \mathrm{In}$ these ways, he casts doubt on the order's canonical legitimacy.

Cano goes on to consider the spirituality of the Jesuits, which he considered, for various reasons, inauthentic. He argues, first, that although the Society is doing apparent good throughout the church, its spiritual fruits are out of season, and not destined to last. People who take the Exercises emerge from their retreat transformed; young novices preach ardent sermons after a brief period of training; and the Society's spiritual children grow to maturity with remark-

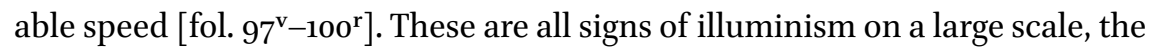
work of the devil who dispenses spiritual gifts liberally in order to lead many astray.

He affirms, secondly, that the members of the Society are not men of proven virtue. This is true of those associated closely with Ignatius: they can show no evidence of the miracles that normally accompany sanctity, and they lack patience, prudence, and humility [fol. $94^{\mathrm{r}} ; 95^{\mathrm{v}}-96^{\mathrm{v}}$ ]. He mentions in particular Miguel de Torres, Pierre Favre, Alfonso Salmerón, and Diego Laínez. The latter two, he alleges, insulted him grossly during a conversation at the Council of Trent. Later they apologized, but the humility with which they expressed remorse was feigned [fol. $\left.96^{\mathrm{r}}\right] .^{56}$ Others are wanting in chastity: he mentions several cases, referring twice to the order of nuns founded by the Countess of Guastalda, with which the Society had close links. This experiment, he claims, ended in sexual licence [fol. $\left.97^{\mathrm{v}} ; 100^{\mathrm{v}}\right] .{ }^{57}$ Jesuits, he adds, take certain substances

55 The reasons for the initial limitation of the number of professed members of the Society are discussed in Bataillon, Les jésuites dans l'Espagne du XVIe siècle, 162-63, and Mongini, "Ad Christi similitudinem," 5on19.

56 On this altercation see the accounts of Jerónimo Nadal, Epistolae (Madrid, 1898-1905), 2:45, and Juan Alfonso de Polanco, Vita Ignatii Loiolae et rerum Societatis Jesu historica (Madrid, 1894-98), 6:640. It is discussed in O'Malley, First Jesuits, 293, and in García Hernán, Ignace de Loyola, 443, who dates it to October 1551.

57 Ludovica Torelli (1499-1569), countess of Guastalda, founded an order of sisters that was formally approved by Pope Paul III in 1535: Giuseppe M. Cagni in Dictionnaire de 
to control their sexual passions, and these give them a pale, deathly look [fol. $\left.100^{\mathrm{r}-\mathrm{v}}\right]$. Such failures in chastity are a further legacy of the dexados who, beginning with a love of prayer, fell first into error and then into sexual sin.

Cano reproaches the Society, finally, for abandoning various features of the religious life that had always expressed and safeguarded the virtue of piety. One of these is public recitation of the divine office, a custom, rooted in the Old Testament and continued by the traditional orders, that Luther had denounced in Germany. The Jesuits were now undermining it in Spain with less clamor but equal efficiency: "Y en España forsan como el Diablo no puede entrar tan abiertamente con dichos entra con hechos; porque esos Padres de su instituto no tienen alabar a Dios en comunidad" [fol.101 $]$. Another is the practice of corporal penance, which previous founders treasured and developed, but which the Society has neglected: "Estos ningunos [ayunos y asperezas] han añadido, ni de coro [...] ni de ayuno, ni de aspereza de vida, ni de vestido, ni de sueño, ni de cama, lo qual hace toda su santidad sospechosa" [fol.102 ${ }^{\mathrm{r}}$ ]. Lastly there is enclosure, a feature of the established orders that fosters holiness in religious who are observant, and protects the world outside from those who are not. The Jesuits have no place for it: "El otro culto de la piedad y Religión es clausura y encerramiento. Estos no tienen ninguno [...] de lo qual no se puede salir sino muy presta salida para ellos y muy gran perdición para la República Christiana" [fol.102 $\left.{ }^{\mathrm{v}}\right]$.

These considerations led Cano to apply to the Society the prophecy of St. Paul that when men of apparent virtue appear in the last days they will "creep into houses and lead captive silly women laden with sins, who are led away with divers desires" [2 Timothy $\left.3: 5^{-6}\right] .{ }^{58}$ The false piety of the Jesuits is not merely a sign of their satanic origin: it is a warning that if they are not stopped they will damage both the church and the state, and bring about in Spain the calamities caused in Germany by the Protestants.

Cano's analysis of the spirituality of St. Ignatius and his followers was challenged vigorously, not only by members of the young Society, but by some of his fellow Dominicans in Spain, ${ }^{59}$ and modern scholarship has confirmed that in many respects it was mistaken. It is true that the inquiries in 1526 into

spiritualité, 15: cols. 1044-48. Members of the Society helped with the spiritual direction of her later foundation (1557), a college for poor noble girls: Ribadeneyra, Confessiones, epistolae aliaque scripta inedita, 2:702, 710, 712. See García Hernán, Ignace de Loyola, 287, 388-9o.

$5^{8}$ On Cano's interpretation of St. Paul's letters as a prophetic warning against the Jesuits see Pozo, “Cano, Melchor," 637, and García Hernán, Ignace de Loyola, 445. 
the apostolate of Ignatius in Alcalá were provoked by the edict against the dexados that had been issued the previous year, ${ }^{60}$ and there is firm evidence that his friends and contacts in the city included some, such as his confessor Manuel Miona (d.1567), who moved in illuminist circles. ${ }^{61}$ On the other hand, there is no indication that Ignatius himself belonged to the group that formed round Pedro Ruiz de Alcaraz and Isabel de la Cruz, and in important ways his teachings differed radically from theirs. The Exercises, for instance, offer a training in mental prayer and reveal a concern to interiorize the Christian life, both characteristics of the alumbrados, but they do not oppose mental to vocal prayer, nor do they criticize external forms of church worship, and they give a central place to the passion of Christ, a devotion that the dexados deplored. ${ }^{62}$

However, Cano's analysis, though inaccurate in many ways, is valuable. It draws attention to several features of Ignatius's spirituality that he shared with the alumbrados, including an aspiration to combine contemplation and action, confidence in the sensible experience of God's love, and faith in the possibility of divine guidance in the ordinary decisions of life. ${ }^{63}$ These parallels help to explain the controversy surrounding the Exercises in his lifetime, and some of the changes of emphasis that occurred after his death, such as the move away from the second time for making an election towards the third. ${ }^{64}$ Cano's passionate conviction that the Society was a "novedad" [fol.104"], breaking with sacrosanct precedents, also helps us to understand the deep hostility aroused by the new order when its foundation was being approved, as well as the decision of Paul IV, once Ignatius had died, to impose on its members

60 Milagros Ortega Costa de Emmart, "San Ignacio de Loyola en el Libro de alumbrados: Nuevos datos para su primer proceso," Arbor 70 (1980): 163-70.

61 Luis Fernández Martín, "Iñigo de Loyola y los alumbrados," Hispania sacra 35 (1983): 585-68o; Pastore, "Unwise Paths"; Sabina Pavone, "A Saint under Trial: Ignatius of Loyola between Alcalá and Rome," in Maryks, A Companion to Ignatius of Loyola, 45-64.

62 Terence O'Reilly, "Saint Ignatius Loyola and Spanish Erasmianism," Archivum historicum Societatis Iesu 43 (1974): 301-21, here 301, 304, 316-17 (reprinted as Essay II in From Ignatius Loyola to John of the Cross); Mark Rotsaert, "Ignatian Spirituality: Some Changes in Vision and Practice," The Way 55, no. 4 (2016): 118-27, here 123-25.

63 The parallels are explored in detail by Mongini, "Ad Christi similitudinem": see especially Chapter Four, 83-130. They are examined also in O'Reilly, "The Spiritual Exercises and Illuminism in Spain."

64 Jacques Roi, "L'élection d'après Saint Ignace: Interprétations diverses," Revue d'ascétique et mystique 42 (1962): 305-23; Alfredo Sampaio, Los tiempos de elección en los directorios de Ejercicios (Bilbao: Mensajero, 2004); Terence O'Reilly, "Joseph Veale and the History of the Spiritual Exercises," Milltown Studies 66 (2010): 1-18. 
an obligation to chant the office in common. ${ }^{65}$ Perhaps it was this decision of the pope, taken in September 1558, that encouraged Cano a few weeks later to consider sending him the Censura. We do not know if Paul IV received it, but if it did come into his hands, the harsh criticism it contains can only have fuelled his misgivings about Ignatius and his resolve to reform the Jesuits.

\section{The British Library Manuscript}

Our knowledge of the text of the Censura may be summarized as follows: (i) a manuscript in the hand of Ramón Cabrera, based possibly on an original in the library of the Dukes of Alba. Published by Miguel Mir in 1900 and 1913; (ii) a printed pamphlet banned by the inquisitor general in 1777 . Seen by Miguel Mir, and used by him in his edition of 1913; (iii) a manuscript in the Roman Archive of the Society of Jesus (ARSI, Hisp. 144). Summarized by Antonio Astraín in 1902. Unpublished;66 (iv) a manuscript in the British Library (Egerton 453, fols. 91-105 ${ }^{\mathrm{v}}$ ). Catalogued by Pascual de Gayangos in 1877, but not analyzed until 1992. Published in 1996;67 (v) further manuscript copies dispersed in Spanish libraries. Reported by Stefania Pastore in 2014, but not detailed. ${ }^{68}$

The British Library manuscript has been described thus by Dr. Barry Taylor: "Egerton Mss $425^{-456}$ are five volumes of 'papeles tocantes a los Jesuitas' formed by Tomás de Iriarte (1750-91), author of the Fábulas literarias and historian. ${ }^{69}$ These tracts are copies, in a variety of seventeenth- and eighteenthcentury hands, of documents dating from 1587 onwards. The latest date mentioned is 1789 (E.g. 452, item 7). The items in E.g. 453 have been reordered: the first item is numbered in a contemporary hand 'Miscelanea No. 6' and foliated in ink 207-224; items 2-4 are numbered 'No. 8,' 'No. 3,' and 'No. 7' respectively. The remainder are not numbered. Cano's Censura is the fourth item in E.g. 453. Page measurements: $215 \times 150 \mathrm{~mm}$; written space: $155 \times 110 \mathrm{~mm}$. The text occupies folios $92-105^{\mathrm{v}}$, preceded by a title leaf (fol. 91), on rougher paper, reading 'No. 7. Jesuitas Censura de M. Cano contra el Instituto de la C[ompañí]a.' The

65 See Marcel Bataillon's study, "Les Iñiguistes et le monachisme," in Les jésuites dans l'Espagne du XVIe siècle, 135-78.

66 I am grateful to the late Antonio Alburquerque, S.J., for supplying me with a copy of the manuscript in Rome.

67 See note 1 above.

68 Pastore, "Unwise Paths," 42n41.

69 Gayangos, Catalogue of the Manuscripts in the Spanish Language, 2:177-8o. Egerton 379 is the correspondence between Iriarte and Eugenio Llaguno y Amirola, dated 1788 (ibid., 1:331). 
text is a fair copy, written in long lines, about twenty to a page, in a single eighteenth- (possibly seventeenth-) century hand. There are changes of ink or pen at folio. ${ }_{102}{ }^{\mathrm{r}}$, line 3, after 'Hay', and folio. $103^{\mathrm{v}}$, line 7 , after 'esto.' There are catchwords at fol. $93^{\mathrm{v}}, 94^{\mathrm{v}}, 95^{\mathrm{v}}, 96^{\mathrm{v}}, 97^{\mathrm{v}}, 99^{\mathrm{v}}, 101^{\mathrm{v}}, 103^{\mathrm{v}}$. The evidence of the watermark (a monstrance with IC in the centre) and the slightly smaller size of folios 100-1 suggest that the following leaves are germinate: 98/99, 100/101, 102/103, giving a collation for this document of seven bifolia."

The transcription of the manuscript that follows observes certain norms: accents have been added, words have been separated or joined (e.g. desto is rendered as de esto), and punctuation has been modified in accordance with modern practice; words underlined in the original have been italicized; $e$ with a cedilla has been rendered as ae; scribal errors have been amended in the text and recorded in the footnotes; folio numbers have been indicated between brackets; scriptural references to the Vulgate Bible have been supplied.

\section{$\left[9^{r}\right]$ Censura y parecer que dio el Padre Maestro Fray Melchor Cano de la Orden de Predicadores contra el Instituto de los Padres Jesuitas}

1. Toda esta materia se reduce a tres puntos. In primo adducuntur ea quae valent in favorem eorum. In secundo ista eadem tanquam suspecta rationibus convincuntur, aut saltem tanquam dubia. Tertio, así de su instituto y manera de vivir como de la divina Escritura y costumbre de la Iglesia en todas las Religiones que ha instituido se convence ${ }^{70}$ el negocio de estos no ir tan ordenado, y que por lo menos se debe sospechar y vehementemente temer que han de ser perjudiciales a España y a toda la Religión Christiana $\left[9^{\mathrm{v}}\right]$.

2. Acerca del primer punto in eorum favorem podemos traer que sus fundadores son buenos. Lo segundo, su institución aprobada por la Iglesia. Lo tercero, que no conocemos en ellos pecados. Lo quarto, que harán mucho provecho: videlicet, dan buen exemplo, son muy devotos, predican buenas $^{71}$ cosas, convierten almas, remedian pobres y hacen otras cosas muy buenas, de los quales frutos dice el Evangelio, "A fructibus eorum cognoscetis eos." 72

\footnotetext{
70 In the manuscript, the word "conoce" has been amended to "convence."

71 In the manuscript "bue" is an overwriting.

72 Mt 7:16.
} 
3. His suppositis pro eorum favore, el Autor frequentibus rationibus et conjecturis destruit atque confundit eorum ordinem eiusque dogmata. Quanto a lo primero, de la santidad de sus fundadores, se supone que Dios como sumamente próvido planta sus cosas no sobre arena o viento $\left[93^{\mathrm{r}}\right]$ sino sobre firmam petram. ${ }^{73}$ Ex quo sequitur que si esta religión es de Dios y no del Diablo que sus primeras piedras o fundamento han de ser muy santos y justos. Supónese lo segundo que el ver que una gente haga mucho provecho espiritual en el pueblo Christiano no convence ni concluye no ser artificio del demonio, pues como solícito engañador de los buenos, ya que no puede por especie de mal, se transfigura algunas veces en ángel de luz, ${ }^{74} \mathrm{y}$ alumbra y da sentimientos espirituales, y aun ayuda de esta suerte a muchos en el camino del cielo para después dar con otros muchos en el camino y hoyo del infierno, como tenemos exemplo manifiesto en España de los Alumbrados y Dexados que fueron primos hermanos de estos, los quales por de- [93 $]$ voción y contemplación y otras cosas divinas hicieron tanto y más fruto que estos Padres, aunque el provecho de esos es más universal, pero pasaron poco a poco (siguiendo la falsa interpretación de aquello del Apóstol San Juan, 1. Canónica, 2: "Unctio eius docebit vos de omnibus") $)^{75}$ a pensar que eran impecables, y que no ${ }^{76}$ habían de hacer sino lo que les venía a la imaginación, por haberse ofrecido todo a Dios. Y de aquí vinieron a pensar que ni la fornicación ni otras cosas semejantes eran pecados, sino que ofreciéndoseles adulterar pensaban que era dictamen del Espíritu Santo, y el ponerlo por obra acto meritorio. Destruyó esta heregía la Inquisición de España, de los quales Hereges aun hasta hoy hay algunos en la cárcel perpetua. De este supuesto se sigue $\left[9^{\mathrm{r}}\right]$ que aunque veamos algunas gentes hacer provecho podemos justamente, atendiendo a otras cosas, sospechar o temer el fruto.

4. Viniendo pues a los fundadores de esta Compañía que llaman de Jesús, el General de ellos es un Iñigo, el qual se escapó huyendo de España porque le quería coger la Inquisición, porque se decía ser de los Alumbrados o Dexados arriba dichos. Fuese a Roma y pidió ser juzgado del Papa, y no habiendo quien le acusase fue dado por libre. Sus compañeros y Apóstoles son Torres, Fabro, Salmerón y Laínez. ${ }^{77}$ Dicamus de singulis.

\footnotetext{
73 Cf. Mt 7:24-27; Lk 6:47-49.

74 Cf. 2 Cor 11:14.

$75 \quad 1$ Jn 2:27.

76 Omitted in the manuscript, which reads "y que habían de hacer."

77 The manuscript reads "Laines." The early Jesuits mentioned are Miguel de Torres, Pierre Favre, Alfonso Salmerón, and Diego Laínez.
} 
Estando el autor una vez en Roma deseó ver a Iñigo, y hablando con él, sin ningún propósito comenzó a hablar con él de su justicia, y de la persecución que le habían hecho en España y quán sin razón, y contó muchas y muy grandes $\left[94^{\mathrm{v}}\right]$ cosas de las revelaciones que tenía de Dios, y eso sin haber ninguna necesidad, lo qual fue ocasión al autor de que le tubiese por vano y no le diese crédito a sus revelaciones. Después de esto tomóle gana de descubrir más, así de su persona como de sus compañeros. Yendo otra vez a comer con él, alabó a un Santo de su Compañía, el qual siendo llamado le pareció al Autor ser loco. Y siendo preguntado de cosas de Dios dixo muchas heregías; y aquello díxolo y hacíalo de idiota, que no sabía más. Y yéndose de allí el sobredicho Santo, quedándose afrentado el Iñigo, dixo al Autor: "Ese no es herege, es loco, y creo tiene lucida intervala; como aora es conjunción de luna, no está tan católico."

5. Ofrecióse otra vez que yendo a hablar al Cardenal Farnesio ${ }^{78}\left[95^{\mathrm{r}}\right]$ con él, salió un page, y preguntando, “¿Quién diré que es?” dixo bien alto: “Decid que es el Maestro Iñigo, o el General de los de la Compañía, o el confesor de Madama, ${ }^{79}$ que por qualquier nombre de estos os entenderá." De lo qual infirió el Autor había allí mucho viento. Hablóle otra vez a un Clérigo Médico que allí estaba de gran Santo, el qual según se supo tenía propósito de estarse en Roma curando toda su vida; y escrudiñando más, se supo que el dicho Santo tenía dos beneficios curados en España, y encomendados a un Letor de Griego en Alcalá que ni los servía ni podía. Sucedió pues que habiendo dado en Roma una bofetada a un seglar sobre no sé qué asientos, y no queriendo el injuriado perdonar, ${ }^{80}$ andando el Iñigo de por medio haciendo las $\left[95^{\mathrm{v}}\right]$ amistades, uno de la Compañía acabó que diese al otro de palos, que él lo sufriría, y así serían amigos, porque así lo había él concertado. ${ }^{81}$ Como el Autor reprehendiese eso respondió el sobredicho Santo que no se había hecho sin consejo de teología, porque se había demandado licencia al Vicario del Papa. De todas estas cosas coligió el Autor ignorancia así del derecho divino como del humano; de beatificar al Médico con los beneficios curados en España y

$78 \quad$ Cardinal Alessandro Farnese.

79 Margaret of Austria.

80 In the manuscript the final " $r$ " is an overwriting.

81 The reading at this point in the Rome manuscript (ARSI, Hisp. 144) offers a clearer account of the incident: "Sucedio que auiendo en Roma vn clerigo dado vna bofetada a un seglar sobre no se que asientos, y no queriendo el injuriado perdonar, auiendo el Inigo estado de por medio haziendo las amistades, vno de la Compania acabo con el injuriado que diese al otro de palos, que el los sufriria y assi serian amigos porque assi lo auia el concertado." 
santificar al loco, igrande imprudencia y indiscreción, y gran vanidad de su trato!

6. El Fabro tubo licencia del Papa para pasar a Alemania y llevar consigo dos clérigos muy necios, y sabido para qué es, para que dixesen misa entre los hereges: cosa de gran vani- $\left[9^{6}{ }^{\mathrm{r}}\right]$ dad. Los otros dos, Salmerón, Laínez, ${ }^{82}$ que fueron al Concilio, hablando una vez con el Autor, dando las razones que tenía para parecerle mal su Orden, como entre otras dixese que era novedad, levantóse uno de ellos diciendo, “¿Novedad? Mas ¡mierda!" Enojado él de semejante desvergüenza, fuéronse los teatinos, y volvieron después a pedirle perdón, fingiendo humildad, con echarle la culpa al injuriado. El otro, Torres, siendo Retor de un Colegio de Salamanca, fue a verse con el Autor, y como beatificase a un Ortiz ${ }^{83}$ de Alcalá dixo de él que murió como un ${ }^{84}$ Santo, y que así había vivido: un hombre que murió a deshora después de haber muy bien cenado, y un hombre que convidándole con la Cátedra de Biblia de Alcalá pidió muchos días de término para $\left[9^{\mathrm{v}}\right]$ que le respondiese el Espíritu Santo, y después pidió tres capitulaciones contra derechos divinos y humanos que tenía aquella Universidad: vivir dentro del Colegio, siendo como era Judío; pidió el primer asiento siendo como era contra leyes de la Universidad; pidió que no le multasen, siendo las multas de los Bedeles. Y como el Torres le escusase nunca dixo que aquello era malo, sino imperfecto. Insuper dixo que como el Espíritu Santo no le inspiraba lo que había de hacer que acordó pedir aquellas condiciones, pareciéndole que si se las concedían el Espíritu Santo quería fuese Catedrático. He aquí muchos ramalazos de Alumbrados o Dexados. Hay otra cosa en esos y en todos los de esta Compañía, que son lisongeros, y entran beatificando $\left[97^{\mathrm{r}}\right]$ a aquellos con quien tratan y hablan, y unos a otros tienen gran cuidado de beatificarse y predicarse por Santos. Es aquello del Apocalipsi: que los cuernos eran como de cordero, y la lengua como de dragón. ${ }^{85} \mathrm{Y}$ como lo de Esaías: Popule meus, qui te beatum praedicant, ipsi se seducunt et decipiunt. ${ }^{86} \mathrm{Y}$ el demonio quando acomete a los buenos por aquí empieza.

7. A lo otro que se puede traer en $\mathrm{su}^{87}$ favor, videlicet que el Papa les confirmó su instituto, se responde que el Pontífice les confirmó el fin de su

\footnotetext{
82 The manuscript reads "Laynes."

83 Dr. Pedro Ortiz.

84 In the manuscript "un" has been added above the line.

85 Cf. Apoc. 13:11.

86 Cf. Isa. 3:12: "Popule meus, qui te beatum dicunt ipsi te decipiunt."

87 The manuscript reads "en su su favor."
} 
orden, scilicet el predicar por el mundo, que es oficio de Apóstoles, y así se llaman ellos los de la Compañía de Jesús, y sus votos. Primero confirmóles el fin sin medio para este fin, lo qual no hizo el sumo Pontífice con Santo Domingo $\left[97^{\mathrm{v}}\right]$ ni San Francisco, con haber hecho milagros y haver visto la visión de la Iglesia de San Pedro que se caía, hasta que le traxeron reglas y constituciones para aquel fin; y entonces les confirmó sus órdenes. Hay también otra cosa, que el Papa confirmó el fin de estos para sesenta y uno para plenu senatu, y por intercesión y soborno de Farnesio (cuya poca santidad todos conocen) y de Madama cuyo confesor era Iñigo. Iten, que en compañía de estos se confirmó la compañía de las Religiosas de la condesa Guastalda, que paró después en acostarse juntos para ver si tenían las pasiones muertas. Haec de eius confirmatione.

8. A lo tercero y quarto que se trae en su favor, videlicet, que porque son buenos, que hacen mucho provecho, y a lo otro que se trae, a fructibus eorum, etc $^{88}\left[9^{8}\right.$ ] . De lo mucho que trae en favor sacó el autor mucha sospecha entre ellos, y explica aquella autoridad attendite a falsis prophetis, etc. ${ }^{89}$ y que cognoscetis eos. ${ }^{90}$ Para conocerlos en los frutos es menester grande atención y consideración: por eso dixo attendite. El ser buenos ellos aora, y al cabo de ${ }^{91}$ quarenta días de exercicios $0^{92}$ al cabo de quatro meses de la Compañía ser Santos y hacer luego Santos a aquellos con quien tratan, no hace por ellos; antes esos son los frutos de los quales dice Christo que les conoceréis, porque esa fruta es ${ }^{93} \sin$ sazón y muy temprana; son los cornezuelos de los Ciruelos. ${ }^{94}$ Unde suspicandum est no sea artificio del Diablo, y la Orden de los Alumbrados más universal, y que el Diablo se transfigura en Ángel de Luz ${ }^{95}$ y los alumbra, y da gus- $\left[9^{\mathrm{v}}\right]$ tos ${ }^{96}$ espirituales para después mejor urdir su trama. Porque el orden que Dios tiene en las cosas espirituales va conforme a las naturales: primero es el hombre niño, después varón, y entonces no engendra varones, sino niños; y así va poco a poco comenzando ab imperfectioribus subiendo ad perfectiora. Así es en la vida espiritual: primero han de ser niños y después paulatim subiendo hasta venir a ser varones perfectos, y aun entonces no han

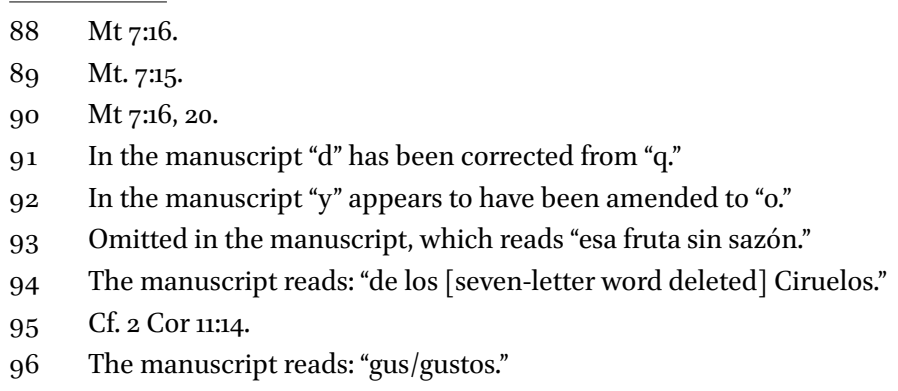


luego de primo instantia y de improviso engendrar varones perfectos, sino niños. En estos Padres es todo lo contrario: pues fruto es del qual les conoceréis. Es fruto antes de tiempo, nuevo, y sin sazón, y contra orden de naturaleza; porque el mal interior no se conoce tan fácilmente; y aun entre $\left[99^{r}\right]$ ellos puede haber muchos engaños que no entiendan. Es ardid del Demonio.

9. Allende de eso, el orden que han tenido todos los Santos que han fundado órdenes es que los Religiosos los vayan criando poco a poco, y esto no en poco tiempo sino en muchos años: en el tiempo del Noviciado, y entre los Novicios, mucha mortificación de sí mismos, mucha disciplina, oración, abstinencia, mucho estudio; y después de siete u ocho años de estudio ad minus que salgan a predicar, y esto no luego a los pueblos grandes sino a las Aldeas. Estos a cabo de quatro meses de exercicios ya les parece son impecables, y así andan predicando en particular, y dando consejos, y hablando del Espíritu Santo, y beatificando las gentes; ergo fruto es nuevo $\left[99^{v}\right]$ a quo cognescetis eos. ${ }^{97}$ No es éste buen medio para instituto de Apóstoles ${ }^{98}$ de Christo, que fue el dechado de todos los que habían de instituir Religiones Apostólicas. Christo nos enseñó cómo se habían de hacer y instituir. Él tubo en su escuela tres años a sus discípulos, y inviándoles a predicar a las Aldeas, y aunque no absolutamente sino ad omnem locum ad quem esset ipse venturus, ${ }^{99}$ para que si hiciesen alguna bobería lo remediase el mismo Christo. Insuper después de haberles dado Christo el Espíritu Santo, qui etiam docuit eos omnem veritatem,100 no permitió que fuesen luego a predicar al mundo, ni que se dividiesen, sino que primero estubiesen juntos diez u doce años, confiriendo unos con otros, teniendo por Maestra a Nuestra Señora y por Ca- $\left[100^{\mathrm{r}}\right]$ beza a San Pedro, y después de esto se dividiesen. Estos luego después de muy pocos días de exercicios luego hacen el oficio de los otros. Luego fruta es temprana. A fructibus, etc.

10. Otra fruta de los verdaderos Profetas es paciencia y humildad. Experiencia tenemos en la fingida de Salmerón y Laínez, ${ }^{101}$ milagros en su cabeza ningunos, cosa hasta hoy nunca vista en los que han fundado Religiones aprobadas desde San Basilio hasta la última de los Mínimos. Después de esto hace grande sospecha el color, videlicet, que todos traen, que debe

\footnotetext{
97 Mt. 7:16, 20.

98 The manuscript reads "Aposto-."

99 Cf. Lk 10:1.

100 Cf. Jn 16:13.

101 The manuscript reads "Laynes."
} 
ser exterminatio faciei; ${ }^{102}$ porque sabe el autor de cierta ciencia que a una muger para que refrenase las pasiones le dieron por consejo tomase el alcanfor, y a otra ad exterminandam faciem $\left[100^{v}\right]$ le dixo otro que bebiese agua de esparto. Y aumenta más la duda ver que todos ellos traen un color. Los ayunos y huevos ${ }^{103}$ con hacer peor sangre no suelen quitar a todos el buen color. Estas cosas dichas parece que hacen algún tanto sospechosas las cosas de estos. Insuper aconteció a uno que traía las manos por los pechos de una moza que confesaba, y dixo que lo hacía por ver si tenía las pasiones muertas; y otro besando a una muger dixo que no era pecado, porque San Pablo dixo: Salutate priscam in osculo sancto. ${ }^{104}$ Las quales cosas todas parece que frisan con los Alumbrados y Dexados, o parece que tiran a los de la Orden de la Condesa Guastalda, prima hermana de estos.

11. Vengamos al punto tercero $\left(101^{\mathrm{r}}\right)$ que prometimus al principio. El Apóstol San Pablo 1. ad Thimotheum 8: Erunt in novissimis diebus homines speciem pietatis habentes, et virtutem eius abnegantes, penetrantes domos, qui captivas ducunt mulierculas. ${ }^{105}$ Esta autoridad parece claro verificarse de aquesta gente al pie de la letra. Porque traen especie de piedad, ut oculis videtur, videlicet, in mortificatione et cultu divino, porque eso quiere decir piedad. Nam est in Deum et parentes ejus. ${ }^{106}$ Tamen virtutem abnegantes. Una de las virtudes y fuerza del divino culto es que Dios se alabe con alabanzas públicas, y esto juntos en comunidad los Religiosos y fieles. La qual costumbre ha usado siempre la Iglesia desde su principio, y se levantan todos en tres vigilias y nocturnos a alabar a Dios. Y en la Iglesia que tubo Dios [101 $\mathrm{v}$ ] antiguamente, videlicet en la Sinagoga, David puso Cantores que alabasen a Dios, ${ }^{107} \mathrm{y}$ hasta aora las Religiones siempre han llevado ese culto aprobado y por costumbre muy adelante; el qual quitó ${ }^{108}$ Lutero en Alemania diciendo quod ille erat labor asinus. Y en España forsan como el Diablo no puede entrar tan abiertamente con dichos entra con hechos; porque esos Padres de su instituto no tienen alabar a Dios en comunidad; imo de su instituto ni rezar las horas Canónicas en particular, sino el que alias tiene obligación de rezarlas ratione ordinis. La

\footnotetext{
102 Cf. Mt 6:16.

103 The manuscript reads "hueva."

104 Cf. Mt 16:20; 2 Cor 13:12; Rom 16:3; 2 Tm 4:19.

105 Cf. $2 \mathrm{Tm} 3: 1,5,6$. The reference in the text to $1 \mathrm{Tm} 8$ is erroneous.

106 Cf. Summa theologiae, 2-2 q.101; q.121.

107 Cf. 1 Chron. 16:4-6; 23:5-6; 25:1; 2 Chron. 29:25.

108 In the manuscript the " $\mathrm{i}$ " is an overwriting.
} 
otra, penetrantes domos, captivantes mulierculas, ${ }^{109}$ con llevarles el ánimo con devocioncillas, y con hacer primero que juren in verba Magistri, desaficionándolas con beatifi- $\left[102^{\mathrm{r}}\right]$ carlas y otras cosas, ne alios habeant concilatores.

12. Hay otra cosa, y esto no sé si es artificio del Demonio para después descubrirse, y es que se llegan a gente de toda broza, a casados y Obispos, ora residan, ora no; y así juntarán tantos que si después descubre la Inquisición algún mal no puede la Inquisición con tantos. Hay otra virtud de piedad y es que todos quantos santos que han hasta aora instituido Religiones siempre sobre los ayunos y asperezas de la Iglesia han puesto y añadido otros. Estos ningunos han añadido, ni de coro como antes decíamos, ni de ayuno, ni de aspereza de vida, ni de vestido, ni de cama, lo qual hace toda su santidad sospechosa. Hay más, que a esta orden se llega $\left[102^{\mathrm{v}}\right]$ gente ambiciosa, videlicet, Judíos y Vizcaynos, los quales in hoc ordine amici facti sunt; ${ }^{110}$ y el clérigo seglar, y el que tiene vendidos los frutos de sus beneficios por muchos años, al cabo de quatro meses de Teatino ya escribe cartas como el Apóstol San Pablo, y por falta de theología scatent erroribus. Hay otra cosa: que su instituto no es de estar encerrados en Colegios que tienen sino de andar por el mundo, y solos, sin otro medio más que los dichos.

13. El otro culto de la piedad y Religión es clausura y encerramiento. Estos no tienen ninguno, sino que pueden salir adonde les pareciere, de lo qual no se puede salir sino muy presta salida para ellos y muy gran perdición para la República Christiana, porque tanto dura $\left[103^{\mathrm{r}}\right]$ una Religión quanto dura su clausura. Porque la clausura sirve ${ }^{111}$ de conservar la santidad todo el tiempo que dura, y sirve después de pérdida para tener los Religiosos encerrados como fieras para que no dañen a otros. Unde como estos Religiosos comiencen por donde los otros acaban y se pierden no puede dexar de durar poco, de lo qual se sigue, aora sean instituidos por Dios, ahora sea artificio del Demonio, que han de caer y ser perniciosos en la República Christiana, porque por el mismo caso que están tenidos por Santos han de querer llevar adelante tal opinión, y como por otra parte caygan han de querer dogmatizar sus errores. De lo qual se sigue claramente o que han de dañar a muchos de secreto con su mu- $\left[103^{\mathrm{v}}\right]$ cha libertad y no diferencia de hábito y gran confianza que los demás tienen de su virtud o santidad, o que, teniendo fuerzas para salir en público,

109 Cf. 2 Tm 3:6.

110 Cf Lk 23:12.

111 The manuscript reads "dirve." 
estragarán la simplicidad y Christiandad de España [...]. ${ }^{112}$ Añádese a esto que como el camino de Dios alius sic, alius autem ${ }^{113}$ sic est, cum Beatus Augustinus distinguat contra quatuor qualitates humorum quatro maneras de Santos, estos tienen para todos unos mismos exercicios de contemplación, como no todos sean aptos para ella: ergo signum est que no permanecerán mucho tiempo. Añádese a esto que con los mismos exercicios hay algunos no tan sanos, ${ }^{114}$ porque post tot septimanas pollicentur gratiam y ternura de corazón y sentimientos espirituales, que parece obligar a Dios, que es $\left[104^{\mathrm{r}}\right]$ un género de tentarle. Lo qual reprendió aquella muger Judith porque habían dicho los de Bethulia que se rendirían si de allí a seis días no les socorría Dios. ${ }^{115}$ Insuper tienen una cláusula no muy sana que dice que quamvis licitum sit apto ad cor complecti, consultius erit quod anima eius maneat in aequilibrio, para hacer lo que Dios le inspirare. Hay también otra cosa, de la qual se puede temer mal, que de la manera que Pelagio vino a levantar tanto el libre alvedrío que negó la necesidad de la gracia de Dios, y Lutero levantó tanto la gracia de Dios que vino a negar el libre alvedrío, así también estos levantan tanto el conformarse con la voluntad de Dios etiam in volito materiali que quieren decir que en ninguna causa nos entris- $\left[104^{\mathrm{v}}\right]$ tezcamos, o a lo menos parece que se debe temer no vengan a esto, comoquiera que Christo se entristeció,116 quamvis cum ratione superiori estuviese conforme a Dios, y ibi sintiese su miseria, aunque hubiese vencido a Dios por ella. ${ }^{117} \mathrm{Y}$ esto de no darse nada ni entristecerse por cosa ninguna es vida contenta, y lo que decía San Pablo: erunt in novissimis diebus homines se ipsos amantes. ${ }^{118}$

14. Conclúyese que pues vemos una novedad como esta, y una cosa hasta ahora nunca usada por los Santos, y una profesión de a cabo de siete años, y las de hasta ahora de año y día, y una gente que se defiende con decir que en habiendo qualquier defecto en los suyos le echan de su Compañía,

112 In the manuscript "España" is followed by six points. It is not clear why.

113 In the manuscript "autem" is added above the line.

114 The manuscript reads "vanos."

115 Jdt 8:9-12.

116 Cf. Mt 26:38.

117 The manuscript reading "aunque hubiese vencido a Dios por ella" may include a scribal error, for it seems to imply that in Gethsemane Christ was prepared to go against his Father's will, an argument that would run counter to the point Cano is making. In the Rome manuscript (ARSI, Hisp. 144) the phrase reads: "y Job sentia su miseria aunque vuiese vencido a Dios por ella."

$1182 \operatorname{Tm} 3: 1-2$. 
y que debemos temer y atender, que si nos dixeran, Hic es Christus in deserto ${ }^{119}$ en lugares $\left[105^{\mathrm{r}}\right]$ y vidas que hasta ahora no han llevado los Santos, que no les creamos. Y si nos dixeren, ecce hic est in penetralibus, ${ }^{120}$ y en nuestra vida secreta, cuyos exercicios non ${ }^{121}$ exhibent hominibus, ut pote legantur, tampoco lo creamus. Nam adventus ejus ut fulgur. ${ }^{122}$ Dios dondequiera que está luego se parece. In secreto, decía Christo, locutus sum nihil. ${ }^{123}$ San Agustín Santo era, y tenía vida Apostólica más que estos, attamen cum mulieribus solus non loquebatur. Y los Apóstoles se marabillaron de Christo de que cum mulieribus solus loqueretur. ${ }^{124}$ Omito etiam que en tratando de Dios la primera tentación del Demonio invisible es querer hablar luego de él en cierto modo, videlicet, que sienta el otro con quien habláis que así lo sentís. De donde se sigue que ofreciéndose la buena consideración luego se ofrece el cómo se ha de decir; lo qual hace que ya ${ }^{125}$ el $\left[105^{\mathrm{v}}\right]$ mantenimiento no harta del todo al alma pues no es comida para ella sola, sino para sí y su compañero con quien trata. Y esto sin entenderlo ellos mismos pasa por sus casas, pues a cabo de quatro días andan luego diciendo sus sentimientos y ternuras, y comenzando sus pláticas y hablas por “iY quán bueno es Dios, y quán amable!”

15. De todas estas cosas infiere el autor que aunque ahora haya muchos buenos de estos que a lo menos est timendum de lo adelante. Unde si alguno me preguntare si tratara con ellos le diré que no, y si me preguntare si tomara su instituto le diré que mucho menos.

\footnotetext{
119 Mt 24:26.

120 Mt 24:26.

121 The manuscript reads "nos."

122 Mt 24:27.

123 Cf. Jn 18:20.

124 Cf. Jn 4:27.

125 The manuscript reads "que ya que."
} 